Ермакова Е.А.

Партнерское взаимодействие работодателей и средне профессиональных образовательных учреждений на рынке образовательных услуг г. Брянска

\author{
Ermakova E.A. \\ Partnerships employers and secondary vocational \\ educational institutions in the educational market of Bryansk
}

В статье поднимается проблема взаимодействия средне профессиональных образовательных учреждений и их социальных партнеровработодателей. Приведены результаты социологического исследования партнерского взаимодействия работодателей и средне профессиональных образовательных учреждений на рынке образовательных услуг г. Брянска

Ключевые слова: социальное партнерство, трудоустройство выпускников, средне профессиональное образование

\section{Ермакова Екатерина Александровна}

Брянский государственный университет им. И.Г. Петровского

2. Брянск, ул. Бежицкая, 14
The article raises the problem of the interaction of secondary vocational educational institutions and social partners-employers. The results of sociological research partnership of employers and secondary vocational educational institutions in the educational market of Bryansk

Key words: social partnership, employment of graduates, secondary vocational education

\section{Ermakova Ekaterina Aleksandrovna} Bryansk state university named I.G. Petrovsky Bryansk, Bezhitskaya st., 14

Одной из актуальных проблем среднего профессионального образования является сотрудничество образовательных учреждений и выпускников колледжей и техникумов со своими социальными партнерами - будущими работодателями. Социальное партнерство представляет систему взаимоотношений образовательных учреждений с предприятиями как субъектами рынка труда, государственными и местными органами власти, общественными организациями в результате, которого происходит выявление, согласование и реализации интересов всех участников этих отношений [5].

Проблемы профессионального образования стали особо актуальны в связи с изменениями, происходящими в институте образования России. Эти изменения касаются не только содержания образовательного процесса, но и социального самочувствия общностей, включенных в этот процесс. Поэтому возникла необходимость социологического исследования не только высшего образования России, но и среднего профессионального образования. 
Исследования социального партнерства в системе среднего профессионального образования показывают, что учебные заведения используют все возможности субъектов рынка труда, государственных и общественных структур, а также заинтересованных лиц в подготовке конкурентоспособных специалистов, поэтому проблема взаимодействия средне профессиональных учреждений и социальных партнеров является актуальной уже много лет и активно исследуется такими социологами как П.Ф. Анисимовым [1, с. 100-107], П.Н Осиповым [4, с. 108-115], А.И. Кравченко, В.И. Добреньковым [3, с. 67], и другими.

В 2015 г. Брянским государственным университетом имени академика И.Г. Петровского было проведено социологическое исследование партнерского взаимодействия социальных партнеров - работодателей и средне профессиональных образовательных учреждений на рынке образовательных услуг г. Брянска. Объектом исследования выступили средние профессиональные образовательных учреждения, в лице педагогических коллективов и работодатели, принимающие на работу выпускников этих образовательных учреждений в течение трех и более лет, предметом - социальные связи профессиональных образовательных учреждений и их социальных партнеров - работодателей. Цель исследования: выявить состояние и закономерности партнерских отношений средне профессиональных образовательных учреждений и их социальных партнеров. Социологическое исследование осуществлялось с помощью анкетирования.

В ходе анкетирования, профессорско-преподавательский и административный состав средне профессиональных образовательных учреждений просили оценить результаты приобретения студентами необходимых компетенций, профессиональных знаний, умений на выходе из образовательного учреждения По мнению респондентов, такие компетенции как профессиональные знания по полученной специальности и профессиональные умения по полученной специальности развиты в полной мере, функциональные навыки и социальные компетенции, личностные качества скорее присутствуют, широта кругозора и большой словарный запас

развиты лишь на половину.

На вопрос «Есть ли в вашем образовательном учреждении центры, службы, программы помощи выпускникам в трудоустройстве?» $72 \%$ опрошенных ответили, что в учреждении есть центры, службы, программы помощи выпускникам в трудоустройстве, $8 \%$ - отсутствуют и $20 \%$ не знают о наличии таких центров и программ помощи выпускникам в учреждении.

Основными формами взаимодействия образовательного учреждения с организациями-работодателями являются такие формы как договоры о прохождении практики студентами, так ответили $46 \%$ респондентов и участие в работе государственных аттестационных комиссий, так ответили $22 \%$ опрошенных.

В ходе анкетирования социальных партнеров-работодателей средне профессиональных образовательных учреждений выяснилось, что 59\% работодателей полностью удовлетворены и $41 \%$ скорее удовлетворены качеством подготовки выпускников средне профессиональных образовательных учреждений.

Работодателей просили оценить уровень подготовки выпускников, каких знаний и умений им не хватает. Оценка компетенций выпускников показала, 
что выпускники имеют хороший уровень подготовки, вполне могут работать по специальности, так считают 59\% респондентов, 33\% считают, что выпускники имеют отличный уровень подготовки и способны выполнить любое задание и лишь 8\% опрошенных считает, что уровень подготовки выпускников посредственный, хотя имеется необходимая база знаний и умений. Основными формами обучения выпускников со среднем профессиональным образованием, не обладающих необходимым уровнем знаний и умений являются такие формы как практическое обучение на рабочем месте опытным специалистом (наставником), так ответило 54\% респондентов и направление на обучение в учебные центры, на курсы повышения квалификации, так ответило 27 \% респондентов.

На вопрос «В каких формах ваша организация взаимодействует с образовательным учреждением, готовящим для вас выпускников со средним профессиональным образованием?» работодатели ответили, что организации взаимодействуют со средне профессиональными образовательными учреждениями на основе договоров о прохождении практики студентами и участие в работе государственных аттестационных комиссий, так ответило 50\% и 30\% респондентов. Только 4\% работодателей заключают целевые договоры о целевой подготовке специалистов и приглашают студентов для участия в совместных исследованиях и разработках.

45 \% работодателей ответило, что на предприятиях отсутствуют специальные программы взаимодействия с образовательными учреждениями, $27 \%$ респондентов ответили, что предприятия взаимодействуют с образовательными учреждениями на основе профориентационных программ, 14\% организуют специальные творческие конкурсы для студентов и 9 \% работодателей готовы поддержать студентов благодаря программе стипендиальной поддержки.

Полученные результаты говорят о том, что социальные партнеры-работодатели средне профессиональных образовательных учреждений имеют заинтересованность и возможность влиять на подготовку студентов в образовательных учреждениях с тем, чтобы затем получать выпускника со среднем профессиональным образованием, полностью готового к работе на предприятии.

\section{Список используемых источников:}

1. Анисимов П.Ф., Гунявина Н.Л. Современный специалист со средним профессиональным образованием: мнение производственников // Социологические исследования. 2002. №12. С. 100-107. 2. Гостенина В.И. Социальное партнерство: приоритеты управления и контроля // Президентский контроль. 2005. №5.

3. Добреньков В.И., Нечаев В.Я. Общество и образование. М., 2003. 381 с.

4. Осипов А.М., Карстанье П., Тумалев В.В., Зарубин В.Г. О социальном партнерстве в сфере образования // Социологические исследования. 2008. № 11. С. 108-115.

\section{(C) 2016, Ермакова Е.A.}

Партнерское взаимодействие работодателей и средне профессиональных образовательных учреждений на рынке образовательных услуг г. Брянска

\footnotetext{
(C) 2016, Ermakova E.A.

Partnerships employers and secondary vocational educational institutions in the educational market of Bryansk
} 